\title{
続発性上皮小体機能充進症に対する手術治療
}

\author{
池田 浩己・熊澤 博文・吉田 智子 \\ 吉永 和化・李 進隆・竹村 景史 \\ 京本 良一・山下 敏夫・西川 光重*
}

\section{Surgical Treatment for Secondary Hyperparathyroidism in our Department}

\author{
Hiroki Ikeda, Hirobumi Kumazawa, Tomoko Yoshida, \\ Kazuhito Yoshinaga, Shinryu Lee, Keiji Takemura, \\ Ryoichi Kyomoto, Toshio Yamashita and Mitsushige Nishikawa \\ (Kansai Medical University)
}

\begin{abstract}
We describe twenty patients with secondary hyperparathyroidism (SHP) treated with surgery. The causes of SHP were chronic renal failure with hemodialysis in all the patients. Twelve patients were male and eight were female, ranging in age from 35 to 63 years. The most frequent complaint before surgery was severe joint pain in the knees, feet, shoulders, back and ankles. Of these complaints, bone pain and pruritus such as irritability, diminished rapidly after surgery. Preoperative examinations with an echogram and scintigram were useful for indicating the number and location of parathyroid glands. Patients were treated with a combination of total parathyroidectomy and autotransplantation of autologous parathyroid tissue to the forearm. There were no complications, such as recurrent nerve palsy and bleeding. We conclude that the combination of total parathyroidectomy and retransplantation of parathyroid tissue is one of the best surgical approaches.
\end{abstract}

Key words : surgical treatment, secondary hyperparathyroidism, retransplantation of parathyroid tissue

\section{はじめに}

続発性上皮小体機能六進症は持続性の低カルシウム血 症により上皮小体の過形成が生じ，上皮小体ホルモン (parathyroid hormone; PTH) の過剩分泌を招く疾患で ある．近年，慢性腎不全に対する治療敊よび血液透析の 進歩による患者の長期生存に伴い, 手術療法を必要とす る患者は年々増加傾向にあるといわれている1)。この続 発性上皮小体機能立進症に対する手術加療に関しては, 外科2), 泌尿器科3) からの報告が多くあるが, 耳鼻咽喉 科からの報告は散見される程度である. 今後患者数が増
加してくれば上皮小体の解剖学的位置から耳鼻咽喉科医 も遭遇する可能性が高くなると考えられる．関西医科大 学では1988年以来, 内科的治療に抵抗する透析患者の続 発性上皮小体機能充進症例に対して，内科と連携し上皮 小体摘出術および前腕筋肉内への自家移植を耳鼻咽喉科 で行っている. 今回この外科的治療経験と術前後の臨床 症状, 生化学的検査の変化に関して若干の文献的考察を 加光報告する。 


\section{対 象}

対象症例は, 関西医科大学第 2 内科沶よび関連病院で 慢性腎不全による血液透析を受けている患者のうち，そ れまでの内科的治療に抵抗性の続発性上皮小体機能六進 症学併発し，外科的治療関西医科大学耳鼻咽喉科に依 頼された20名である。対象期間は1988年 1 月から 1996年 12 月までの 9 年間とした。症例の内訳は男性 12 名, 女性 8 名で, 年齢は35 63歳, 平均年齢48.8歳であった. 透 析歷は36〜264カ月で平均透析歴は149.9カ月であった. 主訴として四肢や腰部の頑固な骨痛拉よび関節痛が20例 全例飞認められた。またその他に頸部腫瘤 5 例，持続す る高カルシウム血症 2 例老認めた。 上皮小体の局在診断 のため術前の画像診断としてェュー, CT, MRI, ${ }^{99 m} \mathrm{Tc}$ $\mathrm{T} 1$ シンチグラムを適宜行った。以上の 20 例飞対する手 術方法として，全身麻酔下に可及的に上皮小体 4 腺を明 視野に置き，全摘出にて迅速病理診断で確認後，最も過 形成の少ない上皮小体を選び，0.5 g 程度をメスにて細 切し前腕筋肉内へ移植した。

\section{結＼cjkstart果}

(1) 術前画像診断

上皮小体の描出率を摘出上皮小体に対与る術前の画像

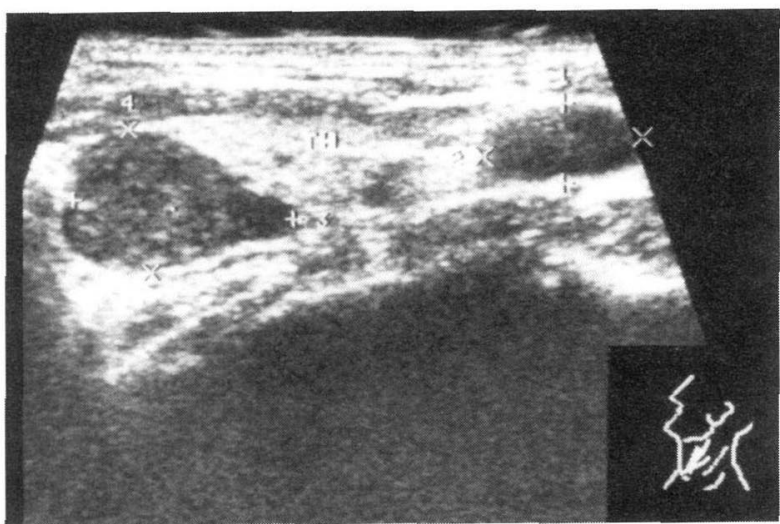

図１続発性上皮小体のエコー図
診断の種類で検討してみると，エコーでは60腺中49腺で $81.7 \%$ と高い描出率だったが，MRI では16腺中 2 腺 (12.5\%)，CT では20腺中 4 腺(20.0\%)であった。その 他 ${ }^{99 \mathrm{~m}} \mathrm{Tc}-\mathrm{Tl}$ サブトラクションシンチグラムでは20腺中 10 腺 (50\%) と此較的よく上皮小体を描出していた。 図 1 に典型的な病的上皮小体のエコ一像示す. 病的上皮小体 の境界は高輝度となり，内側は低ェコーを呈していた。

(2) 手術所見

術野に打ける多くの肥大した上皮小体の検索は比較的 容易であったが，症例により肥大を認めない上皮小体や， 甲状腺より尾側に隔たって存在する上皮小体症例があっ た。 上皮小体の存在が術前に確認できていない場合は， 術中慎重に検索したものの，4腺摘出は15例であった. 今回の総摘出上皮小体 74 腺中の局在を図 2 亿示す。 20 例 中15例では 4 腺摘出したが， 3 腺の久摘出が 4 例， 2 腺 しか確認できなかった症例が 1 例あった。

上皮小体摘出術に際して, 反回神経麻瘦の可能性が出 るが，今回手術を行った 20 例では反回神経麻痺を認めな かったささらに摘出した上皮小体と反回神経との関係を 表 1 に示す. 上皮小体の摘出に際し反回神経と近接して 存在していたのは，特に右上の上皮小体に多かった．

(3) 組織所見

摘出された上皮小体を組織学的に検討したところ，全

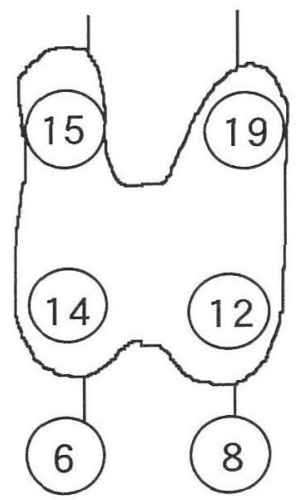

右上一 15 腺 右下一 14 腺 左上一 19 腺 左下一 12 腺 甲状腺下縁下右 -6 腺 甲状腺下縁下左一 8 腺

表 1 反回神経と上皮小体との関係

(腺数)

\begin{tabular}{|c|c|c|c|c|c|c|}
\hline 反回神経との関係 & $\begin{array}{l}\text { 右 上 } \\
(15)\end{array}$ & 左 上 & $\begin{array}{c}\text { 右 下 } \\
(14)\end{array}$ & $\begin{array}{c}\text { 左 下 } \\
(12)\end{array}$ & $\begin{array}{c}\text { 下縁下右 } \\
(6)\end{array}$ & $\begin{array}{c}\text { 下縁下左 } \\
\text { (8) }\end{array}$ \\
\hline 神経との密着 $(+)$ & 5 & 1 & 2 & 2 & 0 & 0 \\
\hline 神経との密着 $(-)$ & 10 & 18 & 12 & 10 & 6 & 8 \\
\hline
\end{tabular}


腺に過形成所見が認められて扣り，多くは結節状の過形 成であった。病理学的には oxyphilic cell, chief cell, clear cell, 脂肪組織からなり, 繊維性隔壁を伴っている, 混合型の adenomatous hyperplasia が注とんどであった. な括 20 例中 1 例に甲状腺乳頭癌の合併を認めた。

（4）術前後臨床経過

術前後の血液学的検査結果の变化を図 3 と示す. 術後, カルシウム值および血清 PTH-C は速やかに低下傾向を 認めたＡLPに関しては著変を認めなかった。

血清 PTH-C は感度は悪いが安定しているので長期の 経過観察には適しているといわれている2). 長期経過観 察ではカルシウム值には著変を認めないが, 血清 PTH$\mathrm{C}$ では 3 年から 6 年後に, 2 腺摘出の 1 例と 3 腺摘出の 2 例で上昇を認めた（図 4 )。術後の注意点として，上皮 小体全摘による低カルシウム血症の治療が挙げられる. 今回われわれが経験した 4 腺摘出し得た 15 例, 打よび慎 重なる検索にもかかわらず 3 腺しか摘出し得なかった 4 例の術後経過は, 注射用カルシウム製剤や経ロカルシウ ム製剤の術直後からの投与により重篤なテタ二一症状の 発現を回避し得た（図 $5 \mathrm{a}, \mathrm{b})$. 今回, 予防的投与にもか かわらずテタニー症状としての口唇の知覚過敏, しびれ
と手指のけいれんまでを自覚し, 注射用カルシウム製剤 の追加を行ったのは 3 腺摘出症例の 1 例のみであった.

\section{考察}

上皮小体機能立進症に対する上皮小体切除が最初に行 われたのは，1960年 Stanbury ら4)によって報告された 亜全摘術である. その後再発を予防する目的で全摘出術 が行われた時期もあるが5)，上皮小体機能低下症による 骨軟化症が生じるため，全摘出術後上皮小体の一部を自 家移植する方法が採用され現在に至っている677). 今回 われわれは上皮小体を摘出後, Wells ら ${ }^{8)}$ の報告に準じ, 前腕の筋肉内に自家移植を行った. 本法は移植片の再腫 大の状態を早期から発見可能であるといら点と，前腕の 移植上皮小体組織の再腫脹時摘出に際し局所麻酔下でで きる利便性が挙げられる.

今回の症例は全例長期透析患者で, 内科的治療に抵抗 するため外科的治療を当科に依頼された．表 2 に1994年 に厚生省の研究班がまとめた上皮小体摘出術の適応を示 す. major criteria は PTH-C の高值, 上皮小体腫大, 線維性骨炎, 内科的治療に抵抗，などが挙げられ minor criteria は表 2 の 1 ～のごとくであり，手術治療を行

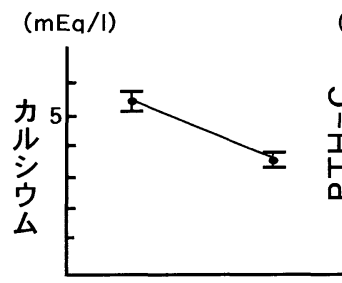

術前

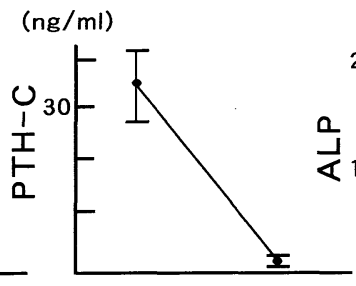

術前

術後

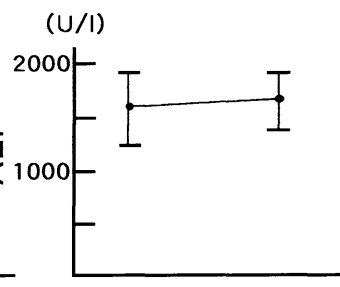

術前

術後

図 3 上皮小体摘出術前後の血液検査結果

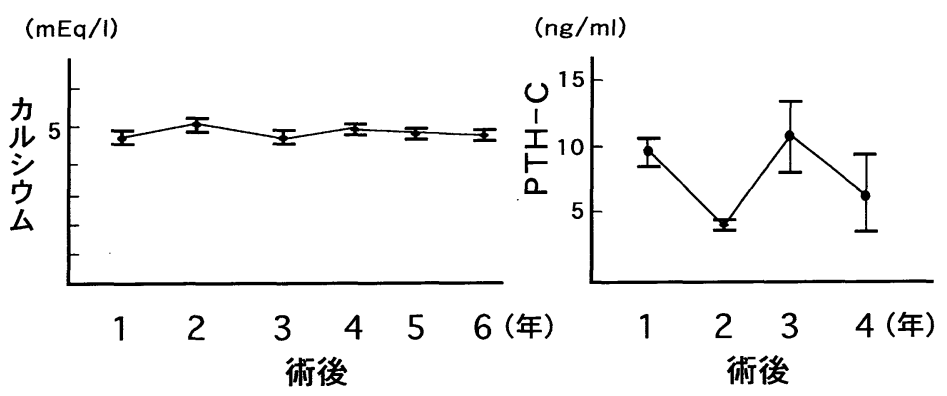

図 4 上皮小体摘出術後の血液検査結果 (長期) 


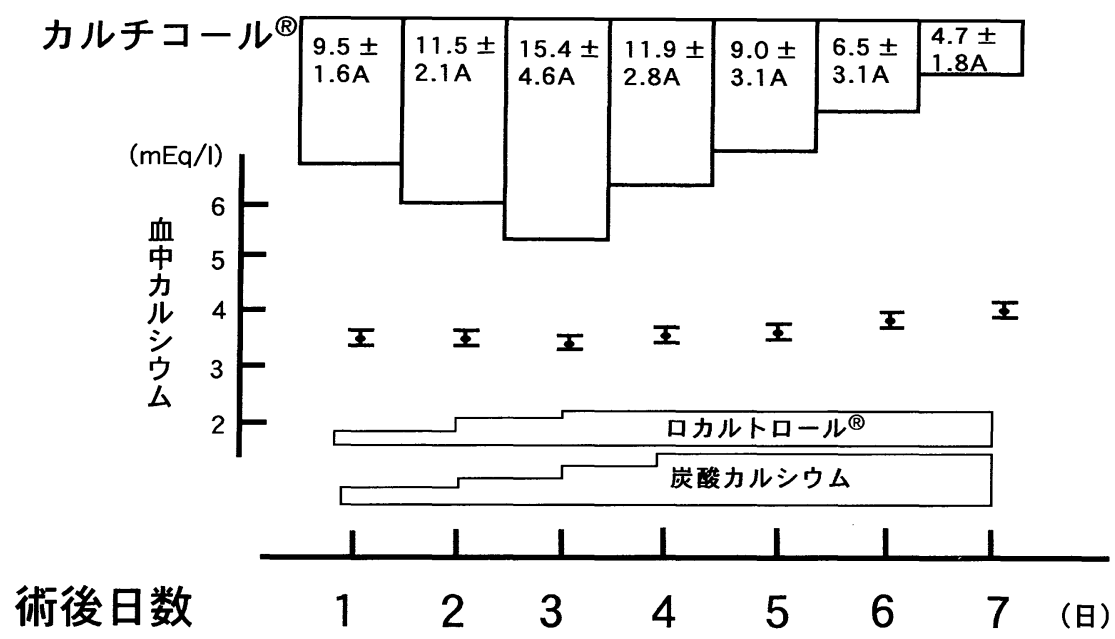

図 $5 \mathrm{a}$ 術後加療経過 ( 4 腺摘出)

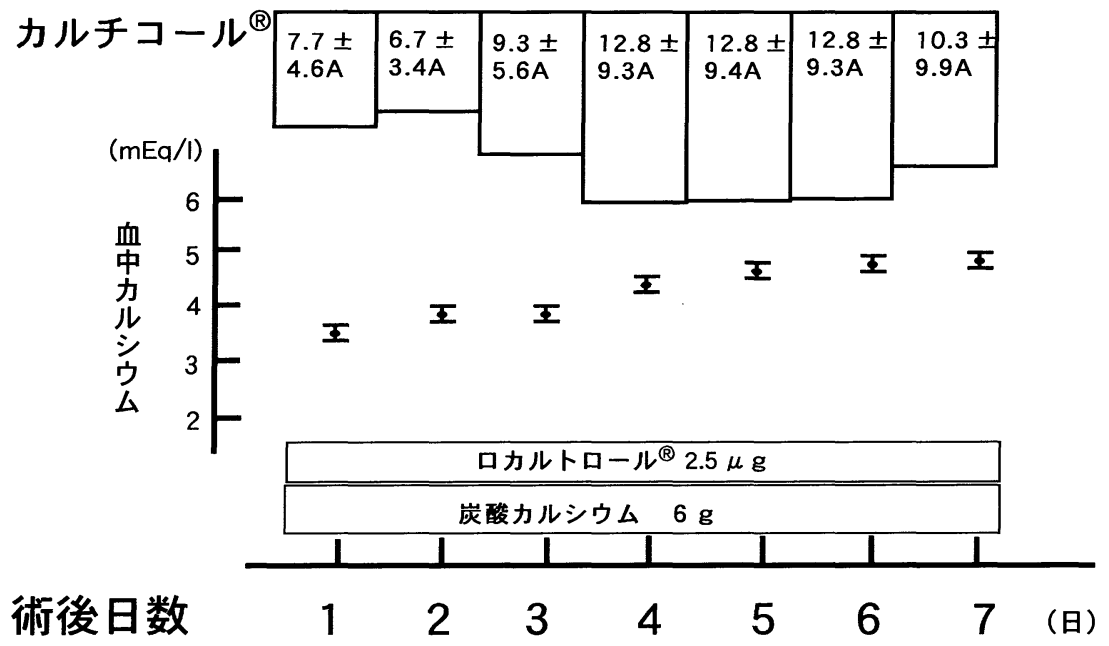

図 $5 \mathrm{~b}$ 術後加療経過 ( 3 腺摘出)

表 2 上皮小体摘出術の施行基準

\footnotetext{
Major criteria 1〜4のすべてを満たす

1. $\mathrm{PTH}-\mathrm{C} \geqq 20 \mathrm{ng} / \mathrm{ml}$ または HS-PTH $\geqq 50 \mathrm{ng} / \mathrm{ml}$

2 .上皮小体腫大(画像診断)

3. 線維性骨炎

4. 内科的治療に抵抗
}

Minor criteria 1 ～4のすべては満たさなくとも下記の所 見によりPTXが必要と判断

1. 高カルシウム血症の持続

2. 異所性石灰化の進行

3 . 重度の骨, 関節症状

4. 治療抵抗性の蛍痒症
らには major criteria 1 〜のすべてを満たすことが必 要である.今回自験例はすべて major criteriaを満たし て物り手術適応と考劣られた。手術時の留意点として， 過形成の上皮小体を摘出するのみならず，過形成のない 残存上皮小体も含めて全摘出することが挙げられる. そ のために術前画像診断は重要であり，過去の諸家の報 告9)10) と同様エコー検査が最も簡便で診断率が高かった.

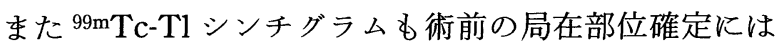
有用であった．検査法による描出率の違いは機種の精度 や施行者の技術的な差によるものと, 本質的に画像診断 
機で描出でさる上皮小体の大きさに限界があるためと考 える、熊澤ら11)も述べたように，約 $5 \mathrm{~mm}$ 以下の大き さでは画像診断での検出が困難であった.

術直後から退院までの短期的な観察すべき点として血 中カルシウムの経過観察が挙げられる. 全上皮小体摘出 後前腕に移植した上皮小体が生着するまでの期間は，通 常カルシウム製剤の点滴投与と経口投与が必要である.

このカルシウム製剤の量に関しては個々の症例毎で変 わってくるが, 今回の検討では, 術後約 1 週間前後には 経ロカルシウム製剤のみで容易にコントロール可能とな ることが多かった，一方，20例中 2 例に術直後の高カリ ウム血症を認め, グルュースーインシュリン療法を施行 した例もあり，慎重に対応する必要があった。このよう に，腎の機能喪失をきたしている長期の透析患者はリス クが大きく, 手術治療の侵襲が予期せぬ状態になること もあるので, 的確に病態を把握し, 内科医との情報交換 を密にしながら術後経過を注意深く観察していくことが 肝要である.

術後に抏ける臨床症状を検討すると，術前にみられた 頑固な骨痛や関節痛および皮膚の搔痒感は術後速やかに 消失していた.PTH に関しては術後 3 年目で 5 例に血 清 PTH-C の高值を認めた. 内訳は 4 腺摘出後と 3 腺摘 出後が 2 例と 2 腺摘出の 1 例である. そのらち 3 腺摘出 後 2 年の 1 例飞破壊性脊椎関節症 (destructive spondyloarthropathy ; DSA) を認めた. 現在 DSA は長期透析 患者に括ける脊椎に括ける関節障害で $\beta 2$-マイクログロ ブリン陽性のアミロイド沈着が原因と考只られている. しかし，骨そのものが腎性異栄湌症を合併しているとも 考兄られ続発性上皮小体機能六進症はDSA 病変の加速 因子であるといら指摘もある12). 今回検討した 20 症例中, 4 腺摘出後 6 年経過と 5 年経過の 2 例に上皮小体組織を 細切, 移植した前腕部の腫脹を認めている.ただし血清 PTH-C が高值の他症例と同様, 骨痛や関節痛はなく現 在のところ臨床的に問題はない. しかし今後再手術も考 慮に入れ経過観察中である.

\section{まとめ}

1. 当科に括ける血液透析中の慢性腎不全に伴ら続発 性上皮小体機能六進症20例の手術治療について報告した。

2. 術前検査ではエコー, シンチグラムが有効である と考えられた.

3. 20例中, 反回神経麻痺や大出血などの副損傷は認
めなかった。

4. 3 次性上皮小体機能元進症や再手術の可能性を考 慮し, 前腕への移植が有用であると考える.

5 . 透析治療が増えていく今後, 内科的治療に抵抗し 骨関節痛を訴兄る続発性上皮小体機能充進症例には内分 泌疾患の特徵を理解した上で, 積極的に手術加療を検討 するべきである.

本論文の要旨は第49回日本気管食道学会総会 (1997年10月 3 日, 旭川)にてロ演した.

\section{参考文献}

1) Takagi H, Tominaga $Y$, Tanaka $Y$, et al : Surgery for renal hyperparathyroidism; experience of 640 cases. Nagoya J Med Sci $60: 15 \sim 22,1997$.

2 ) 戸田 茂, 松田保史, 森田弘毅, 他: 2 次性副甲状腺機能 克進症の外科治療. 臨床今治 $1: 54 \sim 59,1995$.

3 ) 杉村武嗣, 山上征二, 岸本武利, 他: 二次性副甲状腺機能 六進症の手術適応. 大阪透析 $9: 207 \sim 214,1991$.

4) Stanbury SW, Lumb GA and Nicholson WF : Elective subtotal parathyroidectomy for renal hyperparathyroidism. Lancet $1: 793 \sim 798,1960$.

5 ) Felts J, Whitley JE, Anderson DD, et al : Medical and surgical treatment of azotemic osteodystrophy. Ann Intern Med $62:$ 1272 1279, 1965.

6 ) Alveryd A : Parathyroid glands in thyroid surgery. Acta Chir Scand Suppl $389: 1 \sim 120,1968$.

7 ) Wells SA, Gunnells JC, Shelburne JD, et al : Transplantation of parathyroid glands in man; clinical indications and results. Surgery $78: 34 \sim 44,1975$.

8 ) Wells SA, Gunnells JC, Schneider AS, et al : Transplantation of the parathyroid glands in man. Transpl Proc $9: 241 \sim 243,1977$.

9 ）河野信一, 田崎義久, 岩下光一, 他：血液透析患者に拈け る二次性副甲状腺機能立進に対する副甲状腺全摘術および 自家移植術の治療経験. 腎と透析 $6: 153 \sim 159,1988$.

10）牛山知己, 阿曾佳郎 : 副甲状腺腫瘍局在診断のための超音 波装置の開発. 病態生理 $8: 55 \sim 65,1989$.

11）熊澤博文, 山下敏夫, 張 久幸, 他: 副甲状腺腫瘤の外科 的治療例の検討. 耳鼻臨床 $85: 1643 \sim 1649,1992$.

12）谷澤龍彦, 高橋栄明, 山田智晃, 他: 脊椎病変. 整災外科 $39: 219 \sim 225,1966$.

$\left(\begin{array}{l}\text { 原稿受付: 平成 } 10 \text { 年 } 12 \text { 月 } 28 \text { 日 } \\ \text { 原稿採択 : 平成 } 11 \text { 年 } 8 \text { 月 } 25 \text { 日 } \\ \text { 別刷請求先 : 池田浩己 } \\ \text { ₹614-8366 八幡市男山泉 } 19 \\ \text { 関西医科大学附属男山病院耳鼻咽喉科 }\end{array}\right)$ 